\title{
PEMANFAATAN LIMBAH PENYAMAKAN KULIT MENJADI GELATIN UNTUK INDUSTRI PANGAN
}

\section{THE UTILIZATION OF WASTE IN TANNING HIDE TO GELATIN FOR FOOD INDUSTRY}

\author{
Sugihartono \\ Balai Besar Kulit Karet dan Plastik Yogyakarta \\ Jl.Sokonandi No.9 Telp (0274) 563939, 512929 Fax 0272-563655 Yogyakarta 55166 \\ Email : bbkkp@jogjamedianet.com
}

Naskah diterima 5 Juli 2013, disetujui 17 Desember 2013

\begin{abstract}
ABSTRAK
Limbah kulit turunan industri penyamakan kulit termasuk kedalam masalah utama, apabila tidak ditangani dengan baik akan menimbulkan masalah dan pencemaran lingkungan. Pada penyamakan sebanyak $1000 \mathrm{~kg}$ akan dihasilkan kulit samak (leather) 150-200 kg; dan limbah turunannya mendekati sebanyak $850 \mathrm{~kg}$, yang terdiri dari limbah kulit yang berasal dari proses basah / beam house (sebelum penyamakan) sebanyak $80 \%$, dan setelah proses penyamakan / tanning sebanyak 20\% Limbah yang dapat diolah menjadi gelatin untuk industri pangan adalah limbah turunan kulit sebelum proses penyamakan. Proses asam menghasilkan gelatin tipe A dengan rendemen yang lebih tinggi dari pada proses basa. Proses basa menghasilkan gelatin tipe B dengan karakteristik : berat molekul, viskositas, dan kekuatan gel; lebih baik dari pada proses asam. Industri pangan menggunakan gelatin untuk : bahan pembentuk busa, pengikat, penstabil, pengisi, pelapis, pemerkaya gizi, pengendap, pembentuk gel, perekat, peningkat viskositas, pengemulsi, finning agent, crystal modifier dan thickener.
\end{abstract}

Kata kunci : limbah, kulit sapi, gelatin, pangan.

\section{ABSTRACT}

Solid wastes generated from tanning process create a major problem for leather industry, if not handled properly will cause problem and invironmental pollution. The tanning process of $1000 \mathrm{~kg}$ raw hide, will yield $150-200 \mathrm{~kg}$ leather and generated nearly $850 \mathrm{~kg}$ as solid wastes, that is consist of solid wastes generated during pre-tanning processes as much as $80 \%$, while $20 \%$ of of the wastes are caused by post tanning processes. Waste that can be processed into gelatin for food industry are generated during pre-tanning process. Acid process produce type A gelatin, with higher yield than the alkaline process. Alkaline process produces $B$ gelatin with gelatin characteristics such as molecular weight, viscosity, and gel strength is better than the acid process. Gelatin for food industry use : foam-forming, binders, stabilizers, fillers, coatings, nutrien enrichment, precipitate, gelling, adhesive, viscosity enhancers, emulsifier, finning agent, crystal modifier, and tickeners.

Keywords : waste, hide, gelatin, food 


\section{PENDAHULUAN}

$\mathrm{P}$ roduk utama dari pemotongan hewan adalah daging, sedangkan produk sampingnya berupa kulit, tulang, tanduk dan kuku; serta limbah yang antara lain berupa kotoran, darah dan bulu. Dari keseluruhan produk samping, kulit meru- pakan produk yang memiliki nilai ekono mi paling tinggi. Secara ekonomi, kulit memiliki harga 10 $15 \%$ dari harga ternak (Said, 2013) atau sekitar $59 \%$ dari nilai keseluruhan produk samping yang dihasil kan oleh seekor ternak (Wikipedia, 2012. Ockerman dan Hansen 2000 di dalam Triatmojo 2009). Berat kulit sapi 6-8\%, kambing $12-15 \%$ dan domba berkisar antara $8-12 \%$ dari berat tubuh hewan (Triatmojo 2009), dapat dimanfaatkan sebagai bahan baku industri pangan dan bukan pangan. Melalui proses tertentu dapat diolah menjadi kerupuk, gelatin, sepatu, tas, dompet, pakaian, sarung tangan, dan barang kerajinan lainnya.

Jumlah perusahaan yang bergerak pada sub-sektor kulit dan barang dari kulit pada tahun 2010 tercatat sebanyak 662 buah; memberikan nilai tambah sebesar 14.754 milyar rupiah (BPS, 2001-2010). Selama tahun 2012 IMK (industri mene ngah dan kecil) kulit, barang kulit dan alas kaki mengalami pertumbuhan produksi paling tinggi yaitu sebesar $8,89 \%$, sehing ga menjadikannya sebagai primadona pertumbuhan produksi (Suryamin, 2013).

Industri barang kulit dan alas kaki merupakan salah satu mata-rantai dari industri penyamakan kulit. Industri penya makan kulit merupakan industri yang mengolah kulit mentah (hide atau skin) yang bersifat mudah rusak oleh pengaruh fisik, kimia dan aktivitas mikroorganisme; menjadi kulit tersamak (leather), yaitu kulit yang tahan terhadap faktor-faktor penye bab kerusakan tersebut (Alihniar, 2011; Irman, 2011). Penyamakan kulit dilakukan melalui 3 (tiga) tahapan proses utama, yaitu proses pengerjaan basah / beam house, proses penyamakan / tanning, dan proses penyelesaian akhir / finishing (Ano mim. 1996; Zaenab. 2008; Elfrida. 2012 ). Pada setiap tahapan proses dihasilkan limbah yang jika tidak diolah dengan tepat dan baik dapat dipastikan akan mence mari lingkungan (Prayitno, 2009).

Sebenarnya pelaku usaha industri penyamakan kulit sudah memahami tin dakan pengolahan limbah agar lingkung an di sekitar industri tidak tercemar, namun karena memerlukan biaya yang cukup besar, akhirnya industri mengu rangi porsi perhatiannya terhadap pengo lahan limbah (Alihniar, 2011). Sebagai akibatnya limbah yang dibuang ke ling kungan sering menjadi masalah karena masih mencemari lingkungan sekitarnya, melalui air, tanah dan udara (Zaenab, 2008). Sebagai contoh adalah adanya wacana penutupan industri penyamakan kulit oleh UPT-LIK (Unit Pelayanan Terpa du Lingkungan Industri Kulit) Kabupaten Magetan, Provinsi Jawa Timur. Keadaan ini disebabkan adanya keluhan warga tentang pencemaran yang ditimbulkan dari kegiatan penyamakan kulit; selain mencemari sumber air, juga menimbulkan bau yang tidak sedap dan bahkan sebagian warga mengaku sakit (Puspita. 2012; Dewi. 2013).

Oleh karena itu agar industri kulit dan barang kulit dapat tetap berkembang, tanpa keluhan dari masyarakat disekitar lingkungan pabrik, maka pihak industri per lu melakukan pengolahan limbah dengan metoda yang benar sebelum limbah dibu ang ke lingkungan atau mengurangi (mini masi) jumlah limbah yang dihasilkan dengan menerapkan produksi bersih. Secara garis besar penerapan produksi bersih dapat dikelompokkan kedalam lima bagian, salah satunya adalah on-site reuse yaitu mengupayakan penggunaan kembali bahan-bahan yang terkandung dalam limbah, baik digunakan kembali pada proses awal maupun sebagai material input proses lain (Indrasti dan Fauzi, 2009). Pemanfaatan limbah yang demikian akan sangat membantu dalam 
mengurangi jumlah limbah yang ada di lingkungan, dan memberikan nilai tambah secara ekonomi. Pemanfaatannya dapat secara langsung didalam pabrik atau di luar pabrik yang bersangkutan (Hidayah, 2007).

Pada tulisan ini dibahas tentang pemanfaatan limbah kulit menjadi gelatin untuk industri pangan, proses produksi, sifat fisika-kimia serta contoh penggunaan gelatin di industri pangan. Dimaksudkan sebagai informasi tentang pemanfaatan limbah kulit untuk industri pangan serta jalan keluar dalam rangka mengurangi dan menekan jumlah limbah padat.

\section{LIMBAH INDUSTRI PENYAMAKAN KULIT}

Limbah pada kegiatan penyamak an kulit dapat berupa limbah cair, padat, debu/gas dan kebisingan (Anonim, 1996). Limbah cair berasal dari proses peren daman (soaking), proses buang bulu dan pengapuran (unhairing dan liming), pro ses buang kapur (deliming), proses peng kikisan protein (degreasing), proses pikel (pickling), proses penyamakan/krom (tan ning), limbah gabungan termasuk pencu cian, proses retanning, dyeing dan fat liquoring.

Limbah gas bersumber dari bebe rapa peralatan produksi, sedangkan parti kel debu berasal dari proses penyerutan dan pengampelasan (shaving dan buffing). Kebisingan bersumber dari mesin produk si dan unit pembangkit tenaga seperti boiler dan genset.

Limbah padat dapat berupa sisa kulit mentah, jaringan kolagen lain, sisa trimming, fleshing, sisa kulit dari beam house, lumpur termasuk bulu, sisa shaving dan buffing. Limbah padat yang merupakan turunan dari industri penya makan kulit berasal dari setiap tahapan proses; dapat diklasifikasikan kedalam 3 (tiga) kelompok ( Ozgunay, et al. 2007 ) sebagai berikut:

a. Limbah dari kulit yang belum disamak ( trimming dan fleshing ) b. Limbah dari kulit yang telah disamak ( shaving dan buffing dust )

c. Limbah dari pewarnaan dan finishing ( trimming )

Apabila proses penyamakan menggunakan krom, maka dua kelompok terakhir (b dan c) juga mengandung krom. Menurut asalnya, limbah padat yang berupa kulit dapat berasal dari sisa kulit yang belum disamak; baik yang tidak mengandung sulfide maupun yang mengandung sulfide dan limbah kulit yang sudah disamak; biasanya mengandung krom.

Volume limbah padat dipengaruhi oleh jenis dan jumlah kulit yang diproses, tahapan dan lama proses, teknologi yang diterapkan serta cara menjaga kebersihan ( Anomim, 1996). Ozgunay, et al. (2007) menyatakan bahwa volume dan variasi jenis limbah tergantung pada species hewan, kondisi peternakan, cara pemo tongan, kondisi konservasi, tahapan proses penyamakan, peralatan operasi, kualifikasi personel dan penggunaan bahan kimia pada proses penyamakan. Oleh karena itu beberapa penulis atau institusi melaporkan volume limbah padat pada industri penyamakan kulit bervariasi.

FAO (1996) menyatakan bahwa pada pengolahan kulit mentah sebanyak satu ton akan dihasilkan limbah padat sebesar 450-600 kg, yang terdiri dari limbah kulit pada perlakuan trimming, fleshing, wet blue split dan buffing dust. Pada keadaan kering kira-kira setengah dari volume limbah tersebut mengandung krom sebesar 3\%. Badan Pengendalian Dampak Lingkungan (1966) melaporkan bahwa pengolahan satu ton kulit awet garam basah akan dihasilkan limbah padat selain bulu dan lumpur sebagai berikut; fleshing $78-234 \mathrm{~kg}$; splitting $222 \mathrm{~kg}$; shaving $20 \mathrm{~kg}$; dan buffing 5-10 kg.

Kanagaraj, et al. (2006) dan Zafar (2012) menyatakan bahwa keluaran pada pengolahan $1000 \mathrm{~kg}$ kulit mentah (hide) akan dihasilkan kulit (leather) sebanyak $150 \mathrm{~kg}$, dan limbah turunannya sebanyak 
$850 \mathrm{~kg}$, yang terdiri dari hair 2-5\%, skin trimming 5-7\%, fleshing 56-60\%, dan chrome shaving, chrome split serta buffing dust sebanyak 35-40\%. Sedang kan Roqayyah (2011) menyatakan bahwa pengolahan satu metric ton kulit mentah (hide) akan dihasilkan kulit (leather) sebanyak $200 \mathrm{~kg}$ (mengandung $3 \mathrm{~kg}$ kromium), dan limbah padat bukan samak sebanyak $250 \mathrm{~kg}$, limbah padat samak sebanyak $200 \mathrm{~kg}$ ( mengandung 3 kg kromium).

Prosentase limbah padat pada proses pengolahan kulit yang berasal dari proses basah / beam house sebanyak $80 \%$, proses penyamakan / tanning sebanyak $19 \%$ dan proses pengerjaan akhir / finishing sebanyak 1\% (Kanagaraj, et al. 2006). Data ini diperkuat Puntener (1995) di dalam Ozgunay, et al. (2007) bahwa selama proses sebelum proses penyamakan, diturunkan $80 \%$ limbah padat dan setelah proses penyamakan dikeluarkan limbah sebanyak $20 \%$.

Limbah padat termasuk kedalam masalah utama pada industri penyamak an kulit, tidak hanya karena volumenya tetapi juga variasi macamnya. Namun demikian sebenarnya sejumlah besar limbah padat turunan dari industri penyamakan kulit merupakan limbah yang dapat digunakan kembali (re-useable). Limbah padat tersebut dapat dikata gorikan sebagai produk samping yang berguna untuk berbagai keperluan atau digunakan sebagai bahan dasar untuk industri lain, antara lain yaitu sebagai bahan baku industri gelatin.

\section{PEMANFAATAN LIMBAH KULIT}

The International Union Environ ment Commission (IUE-2. 2008) menetap kan aturan bahwa binatang yang terin feksi BSE (Bovine Spongiform Ence phalophaty) secara total harus dimus nahkan, dan tidak mengizinkan untuk menyamak kulit binatang yang terinfeksi penyakit tersebut. Pemanfaatan (re-use) limbah padat pada industri penyamakan kulit sebelum penyamakan/tanning untuk makanan manusia dan binatang dibatasi atau dikendalikan secara seksama.

Beberapa pemanfaatan limbah padat yang berupa kulit dari setiap tahapan proses penyamakan direkomen dasikan oleh IUE-2 (2008) untuk penggunaan sebagai berikut ;

- Trimming (green and limed) yaitu limbah kulit hasil samping dari proses perapian (trimming) kulit segar dan proses pengapuran sebelum disamak, digunakan untuk produksi tallow atau gelatin.

- Limed splits yaitu limbah kulit hasil samping dari pembelahan / splitting pa da proses pengapuran, digunakan un tuk produksi gelatin, bungkus sosis, ma kanan binatang piaraan (dog chews) dan kompos. Gelatin dari limbah ini dapat digunakan pada industri makan an (food), photografi, dan pharmasi.

- White splitting yaitu limbah kulit hasil samping dari proses pembelahan / splitting pada proses penyamakan nabati, digunakan untuk produksi gelatin atau kollagen additives, tetapi penggunaannya sebagai makanan manusia dibatasi.

- White shaving yaitu limbah kulit hasil samping dari proses pengetaman / shaving kulit yang disamak ramah ling kungan ( bahan penyamak dapat beru pa aldehid, syntan, bahan nabati ), digunakan untuk pupuk atau hidrolisat kollagen. Alumunium yang dikandung, dapat diaplikasikan untuk tanah pertanian yang tidak asam sesuai aturan daerah.

- Blue splits dan shavings yaitu limbah kulit hasil samping dari proses pembelahan / splitting dan pengetam an / shavings kulit yang disamak kimia (krom), digunakan untuk pembuatan papan kulit (leather board), produksi sodium 
chromate, hidrolisat atau gelatable protein, bahan campuran pembuatan batu-bata (brick). Disam ping itu juga untuk gelatin dengan cara mencampur shaving dengan magne sium oksida dan kemudian mengguna kan air panas diperoleh ekstrak gelatin sebanyak 50\%. Protein cair dapat digunakan untuk keperluan industri.

Dari uraian tersebut dapat dikemu kakan bahwa IUE-2 (2008) tidak mereko mendasikan semua limbah padat yang berupa kulit dari setiap tahapan proses penyamakan kulit digunakan gelatin untuk pangan. Limbah sebelum proses penya makan direkomendasikan untuk produksi gelatin dan boleh digunakan untuk industri pangan tetapi limbah setelah proses penyamakan (b/ue splits dan shavings) tidak direkomendasikan untuk gelatin pangan.

Teknologi baru penyamakan kulit ramah lingkungan, menggunakan bahan penyamak nabati seperti mimosa, gambir dan quebracho merupakan bahan penya mak bukan mineral dan bersifat ramah lingkungan (Suparno dkk, 2010). Keadaan ini memungkinkan semua jenis limbah kulit pada industri penyamakan kulit boleh diolah menjadi gelatin pangan.

Vaskova, et al. (2013) menyatakan bahwa krom valensi $3\left(\mathrm{Cr}^{+3}\right)$ berikatansilang ( crosslinking ) dengan serat kola gen kulit, dan dapat memenuhi kualitas yang dikehendaki. Pada kondisi yang beragam, sejumlah kecil $\mathrm{Cr}^{+3}$ dalam kulit dapat dioksidasi menjadi krom bentuk lain yaitu krom heksavalen $\left(\mathrm{Cr}^{+6}\right)$. Krom hek savalen $\left(\mathrm{Cr}^{+6}\right)$ bersifat toxid dan diklasifi kasikan sebagai karsinogen. Pengeta huan tentang konversi

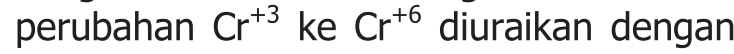
baik didalam pusta ka, namun mekanisme komplek yang te pat dan detil tidak dapat diterangkan seca ra jelas. Walapun krom dapat dipisahkan dari kulit, namun untuk kehati-hatian seba iknya limbah kulit samak krom tidak dipro ses menjadi gelatin pangan.

\section{GELATIN}

Gelatin merupakan suatu jenis protein yang diekstraksi dari jaringan kolagen kulit, tulang atau ligamen (jaringan ikat) hewan ( Fauzi, 2007), biasanya sapi dan babi ( Mc Nulty, 2002) dan dapat juga dari kulit ikan ( Chaplin, 2012). Dalam Food Chemicals Codex, gelatin didefinisikan sebagai produk yang diperoleh dari hidrolisis kolagen secara asam, basa, atau ensimatis, pada kulit, tulang, jaringan ikat hewan, termasuk ikan dan unggas (Anonim, 2012).

Untuk memenuhi keperluan industri dalam negeri, Indonesia setiap tahunnya masih mengimpor gelatin dalam jumlah cukup banyak dan cenderung mengalami peningkatan. Pranoto

(2008) menyebutkan, bahwa impor gelatin Indonesia menurut data BPS 2007 mencapai $2.715 .782 \mathrm{~kg}$ dengan nilai sebesar 9.535.128 dolar AS. Disisi lain kebutuhan gelatin di pasar internasional juga tetap tinggi. Pemakaian gelatin sebagian besar digunakan untuk industri dibidang pangan, jumlahnya mencapai $70 \%$ dari total produksi gelatin dunia.

Indonesia memiliki beragam bahan baku yang dapat dipergunakan untuk produksi gelatin, diantaranya adalah limbah industri kulit yang selama ini belum dimanfaatkan secara optimal (Hambali dan Suryani, 2001), tulang dan kulit sapi, kulit babi dan kulit ikan (Anonim, 2010). Pemanfaatan limbah kulit untuk produksi gelatin tersebut disamping dapat menekan jumlah limbah dan mengurangi pencemaran lingkungan, juga dapat memberikan nilai tambah ekonomi pada industri kulit dan lapangan berusa ha baru. Keuntungan lainnya antara lain adalah, menjamin kelangsungan beru saha industri penyamakan kulit (karena berkurangnya cemaran pada lingkungan yang pada gilirannya dapat mengurangi bahkan meniadakan keluhan warga akibat cemaran industri ), peningkatan peman faatan penggunaan kulit, penciptaan 
lapangan kerja dan mengurangi ketergantungan impor.

\section{Tipe-tipe Gelatin}

Secara umum terdapat dua jenis gelatin, yaitu tipe A (acid) dan tipe B (base). Gelatin tipe A adalah gelatin yang diperoleh dengan cara pengasaman; mempunyai titik isoelektrik antara $\mathrm{pH} 6$ dan 9. Biasanya secara khusus diproduksi dari kulit babi. Gelatin tipe B adalah adalah gelatine yang diperoleh dengan cara alkali; mempunyai titik isoelektrik antara 4,7 hingga 5. Diproduksi dari kulit sapi, kambing dan kerbau atau tulang binatang yang sudah dihilangkan mineralnya (Jaswir, 2007).

Hambali dan Suryani (2001) menyatakan bahwa kulit sapi dapat diproses menjadi gelatin tipe $A$ dan tipe $B$. Gelatin tipe A dihasilkan melalui ekstraksi bertahap (tiga tahap) menggunakan pelarut $\mathrm{HCl} 15 \%$ pada proses liming selama 10 -20 jam. Gelatin tipe B juga dihasilkan melalui ekstraksi bertahap (tiga tahap) menggunakan pelarut $\mathrm{NaOH} 24$ \% selama 15 -25 jam. Gelatin yang dihasilkan dapat dimanfaatkan pada berbagai industri pangan ataupun bukan pangan, yaitu sebagai pengental, peng emulsi, dan penstabil emulsi.

\section{Proses Produksi Gelatin dari Limbah Industri Kulit}

Bahan dasar untuk produksi gelatin industri pangan yang berasal dari limbah industri penyamakan kulit berupa limbah kulit sebelum proses penyamakan yaitu trimming (green and limed), limed split, dan limbah kulit setelah proses penyamakan nabati, yaitu white splitting dan white saving (IUE-2. 2008). Dalam uraian berikut hanya akan disajikan produksi gelatin dari bahan limbah kulit sapi sebelum proses penyamakan.

Tipe gelatin yang dihasilkan tergan tung dari proses yang digunakan, yaitu proses asam atau proses basa. Proses asam pada hidrolisis kolagen dipengaruhi oleh; perbandingan zat pereaksi, katalisa tor, waktu dan suhu reaksi serta peng adukan ( Hastutiningrum, 2009), dan juga konsentrasi asam dalam hal ini asam asetat ( Ulfah, 2011 ) serta jenis asam (Martaningsih, 2010).

Proses asam akan menghasilkan rendemen gelatin yang lebih baik dari pada proses basa; tetapi bila berdasarkan karakteristik gelatin seperti viskositas, berat molekul, dan kekuatan gel, maka proses basa lebih baik dari pada proses asam ( Nurhalimah, 2010 ).

Proses produksi utama dalam pem buatan gelatin dibagi dalam tiga tahap, pertama persiapan bahan baku, kedua konversi kolagen menjadi gelatin dan ketiga pemurnian gelatin serta perolehan gelatin dalam bentuk kering (Anonim. 1990).

Secara garis besar setiap tahapan proses basa pengolahan gelatin dari limbah industri penyamakan kulit diurai kan sebagai berikut; tahap persiapan bahan meliputi; penghilangan komponen bukan kolagen, pengecilan ukuran dan pencucian. Tahap kedua konversi kolagen menjadi gelatin dan tahap ketiga pemur nian gelatin meliputi : perendaman dalam larutan kapur ( liming ) selama waktu tertentu, kemudian penghilangan kapur (deliming) pada kulit dengan mengguna kan air dan larutan asam organik atau anorganik. Langkah berikutnya adalah proses ekstraksi bertingkat. Selanjutnya penyaringan menggunakan penyaring vakum dan filtrat yang diperoleh di murnikan dengan menggunakan pertukar an ion dan kation resin. Kemudian dipekatkan dengan menggunakan evapo rator dan disterilisasi; gelatin pekat didinginkan selanjutnya dikeringkan pada suhu $60^{\circ} \mathrm{C}$ sampai kadar ainya menjadi $10 \%$.

Asam organik yang biasa digunakan pada proses produksi gelatin antara lain adalah asam asetat, sitrat, fumarat, askorbat, malat, suksinat, dan tartarat. Sedangkan asam anorganik antara lain 
adalah; asam hidroklorat, asam fosfat, dan asam sulfat.

Kondisi operasi yang paling menguntungkan pada ekstraksi bertingkat adalah sebagai berikut; tingkat pertama menggunakan suhu $64^{\circ} \mathrm{C}$, waktu 5 (lima) jam, keasaman $(\mathrm{pH})$ netral; tingkat kedua menggunakan suhu $74^{\circ} \mathrm{C}$, waktu 3,72 jam, keasaman $(\mathrm{pH})$ netral; tingkat ketiga menggunakan suhu $84^{\circ} \mathrm{C}$, waktu 3,69 jam, keasaman $(\mathrm{pH})$ netral; dan tingkat empat menggunakan suhu $98^{\circ} \mathrm{C}$, waktu 3,83 jam, keasaman $(\mathrm{pH})$ netral. Pada kondisi ini diperoleh rendemen sebesar 13,6\% (Barbooti, et.al., 2008). Hasan (2007) melaporkan, rendemen gelatin dari kulit sapi yang di proses secara basa berkisar antara $6,46 \%$ sampai $13,11 \%$

\section{Sifat Fisik dan Kimia Gelatin}

Gelatin merupakan turunan protein dari serat kolagen yang ada pada kulit, tulang dan tulang rawan. Apabila didihkan dalam air yang dikombinasikan asam atau basa, kolagen akan mengalami transfor masi menjadi gelatin. Gelatin memiliki sifat yang khas yaitu dapat berubah secara reversible dari bentuk sol ke gel, larut dalam air, mengembang dalam air dingin, dapat membentuk film, mempengaruhi viskositas suatu bahan, dan dapat melindungi koloid (Parker, 1982 di dalam Junianto dkk. 2006). Pada suhu $71^{\circ} \mathrm{C}$ mudah larut dalam air dan membentuk gel pada suhu $49^{\circ} \mathrm{C}$ ( Wahyuni dan Perangin angin, .2008). Gelatin ikan mempunyai titik leleh lebih rendah dari pada gelatin babi dan daging ( Choi and Regenstein, 2000).

Secara organoleptik gelatin ikan lebih baik dalam melepaskan aroma dan memberi flavor yang kuat (Choi and Regenstein 2000), pada umumnya.gelatin hampir tidak berasa dan berbau (Singh. et al. 2002, Jaswir 2007 dan Anomin, 2012 ). Dari segi fisik, bersifat seperti kaca, merupakan subtansi padat rapuh (brittle), tidak berwarna sampai kuning lemah (Anomin, 2012 dan Jaswir 2007). Gelatin kering berkadar air $8-13 \%$, memiliki densitas relatif $1,3-1,4$; dan berat molekul berkisar antara 15.000 400.000. Gelatin merupakan hydrophilic biopolimer dapat berinteraksi khususnya dengan air dan mengalami perubahan sifat fisik-mekanik yang drastis tergantung pada kandungan airnya (Kozlov, 1983). Apabila direndam dalam air dingin akan mengembang dan apabila dipanaskan akan membentuk larutan. Sifat kelarutan gelatin dipengaruhi oleh : suhu, $\mathrm{pH}$, kadar abu, metoda pembuatan dan konsentrasi. Gelatin tidak dapat larut dalam pelarut organik yang kurang polar seperti benzen, aseton, alkohol primer dan dimetil formamid (Anomin, 2012), kloroform, ether, etanol (95\%), dan metanol ( Singh. et al. 2002 ).

Elemen dasar penyusun gelatin adalah; karbon 50,5\%, hidrogen $6,8 \%$, nitrogen $17 \%$, dan oksigen $25,2 \%$ (Anomin, 2012). Gelatin kering mengandung; protein $84-86 \%$, air 8 - $12 \%$, dan mineral 2 - $4 \%$ ( Fauzi, 2007). Asam amino penyusun gelatin bervariasi, tergantung bahan dasar dan proses yang digunakan. Sebagai gambaran asam amino penyusun gelatin (berdasarkan persen berat) adalah sebagai berikut : glisine $21 \%$, proline $12 \%$, hidroksi proline $12 \%$, asam glutamat $10 \%$, alanin $9 \%$, arginin $8 \%$, asam aspartat 6\%, lisin 4\%, serin $4 \%$, leusin $3 \% \%$, valin $2 \%$, penilalanin $2 \%$, treonin $2 \%$, isoleusin $1 \%$, hidroksilisin $1 \%$, metionin dan histidin $<1 \%$ serta tirosin $<0,5 \%$ ( Cole dan Francis, 2000). Gelatin dianggap sebagai protein tidak lengkap karena kekurangan salah satu asam amino esensial yaitu triptopan (Saleh, 2004 ) serta rendah sistein dan tirosin (Jaswir, 2007). Walaupun demikian gelatin memiliki daya cerna sangat baik dan sering digunakan untuk memberi makanan bagi penderita penyakit. Berdasarkan hasil studi, memperlihatkan bahwa konsumsi gelatin 7 - 10 g/hari seca ra nyata dapat memperbaiki kecepatan pertumbuhan dan kekuatan gigi, serta pertumbuhan rambut (Cole dan Francis, 2000). 
Sifat penting dari gelatin adalah kekuatan gel (gel strength) yang dikenal dengan kekuatan Bloom. Berdasarkan kekuatan Bloom, gelatin diklasifikasikan sebagai Bloom rendah $(<150)$, sedang (150-220), dan tinggi (220-300). Keku atan gel tergantung konsentrasi gelatin, sifat-sifat kekuatan dari dalam (intrinsic) gelatin, $\mathrm{pH}$, suhu, dan bahan aditif. Sifat kekuatan dari dalam (intrinsic) gelatin merupakan fungsi dari struktur dan berat molekul gelatin (Anonim, 2012). Gelatin dengan kadar asam amino tinggi akan memiliki kekuatan gel lebih tinggi (Pranoto, 2008).

Sifat penting lainnya adalah sifat ampoter ( Saleh, 2004 ) yaitu gelatin mampu bertindak sebagai asam atau basa pada waktu bersamaan. Dalam industri sifat yang demikian akan sangat bermanfaat (Jaswir, 2007). Gelatin tipe A memiliki titik isoelektrik antara $\mathrm{pH} 7$ 9, sedangkan tipe $\mathrm{B}$ memiliki titik isoelektrik antara pH 4,7 - 5,4 (Anonim, 2012).

Gelatin juga memiliki sifat korosif, walaupun stainless steel (s/s) tipe 304 dapat digunakan untuk memproses susu, namun dengan adanya gelatin akan menyebabkan tabung tipe 304 dapat berlubang setelah digunakan secara kontinu dalam kurun waktu beberapa bulan. Dibutuhkan s/s tipe 316 dengan kandungan molibdenum rendah untuk memproses susu dengan gelatin, s/s tipe 316 dengan kandungan molibdenum 2\% sudah tidak dapat diterima (Cole dan Francis, 2000).

\section{Pengunaan Gelatin Untuk Industri Pangan}

Gelatin lebih baik diperhatikan sebagai bahan tambahan pangan (food additive) dari pada sebagai unsur bahan pangan (food ingredient) dan telah digolongkan dalam GRAS ( Generally Regarded As Safe). JECFA (Joint Expert Commission on Food Additive) mulai ta hun 1970 tidak membatasi jumlah peng gunaan gelatin. Gelatin merupakan media yang sangat cocok untuk pertumbuhan bakteria, sehingga produsen harus peduli untuk menerapkan program HACCP dan mengimplementasikan sistem manajemen mutu ISO 9000 (Cole dan Francis, 2000).

Menurut Gelatin Manufacturers Institute Of America (Anonim, 2012), ciriciri spesifikasi gelatin yang dapat dimakan (edible gelatin) adalah seperti disajikan pada Tabel 1 berikut;

Tabel 1. Spesifikasi Gelatin Tipe A dan Tipe B Yang Dapat Dimakan.

\begin{tabular}{|c|c|c|}
\hline Parameter & Tipe & Tipe \\
\hline & $3,8-5,5$ & $5-7,5$ \\
\hline Titik Isoelektris & $7-9$ & $4,7-5,4$ \\
\hline (Bloom) & $50-300$ & $50-300$ \\
\hline Viskositas(mps) & $15-75$ & $20-75$ \\
\hline Abu & $0,3-2$ & $0,5-2$ \\
\hline
\end{tabular}

Sumber : Anonim 2012, hal 12.

Penggunaan gelatin dalam industri pangan sangat luas, karena gelatin dapat berfungsi sebagai bahan pengisi, pengemulsi, pengikat, pengendap, pemerkaya gizi, dan dapat membentuk lapisan tipis yang elastis, membentuk film yang transparan dan kuat, serta memiliki daya cerna tinggi ( Fauzi, 2007). Wahyuni dan Peranginangin (2008) menyatakan gelatin pada industri pangan digunakan sebagai bahan pembentuk busa, pengikat, pensta bil, pembentuk gel, perekat, peningkat vis kositas, pengemulsi, finning agent, crystal modifier dan thickener.

Jaswir (2007) menyatakan fungsi gelatin di dalam industri pangan adalah untuk meningkatkan elastisitas, konsisten si, dan stabilitas produk pangan yang diha silkan. Disamping itu gelatin dapat mem bentuk gel, dan sesuai suhu bersifat rever sible, dan gel akan meleleh dibawah suhu tubuh yaitu $<35^{\circ} \mathrm{C}$ (Pranoto. 2008). Sifat gel gelatin yang dapat meleleh dibawah suhu tubuh membuat gelatin dapat mem berikan sensasi rasa yang lebih baik 
sehingga sering digunakan sebagai peng ganti lemak (Jaswir, 2007).

Beberapa contoh penggunaan gelatin pada berbagai produk pangan seperti yang dikemukakan Pranoto (2006) dan Fauzi (2007) adalah sebagai berikut:

- Produk daging olahan: berfungsi untuk meningkatkan daya ikat air, konsistensi dan stabilitas produk sosis, kornet dan ham.

- Produk susu olahan : berfungsi untuk memperbaiki tekstur, konsistensi dan stabilitas produk, menghindari sineresis pada yoghurt, es krim, susu asam dan keju cottage.

- Produk bakery: berfungsi untuk men jaga kelembaban produk, sebagai pe rekat, bahan pengisi pada roti-rotian.

- Produk minuman: berfungsi sebagai penjernih sari buah ( juice ), bir dan wine (anggur).

- Produk buah-buahan : berfungsi seba gai pelapis ( melapisi pori-pori buah sehingga terhindar dari kekeringan dan kerusakan oleh mikroba ) untuk men jaga kesegaran dan keawetan buah.

- Produk permen dan sejenisnya: berfungsi untuk mengatur konsistensi produk, mengatur daya gigit dan kekerasan serta tekstur produk, mengatur kelembutan dan daya lengket dimulut.

- Jenis produk secara umum: berfungsi sebagai zat pengental, penggumpal, membuat produk menjadi elastis, pengemulsi, penstabil, pembentuk busa, pengikat air, plapis tipis dan pemerkaya gizi ( Fauzi, 2007).

Purwanto (2006) melaporkan bahwa penambahan gelatin B sebanyak $0,6 \%$ berpengaruh terhadap tekstur yoghurt beku, selanjutnya Wulandari (2012) menyatakan, bahwa kesegaran buah jeruk dapat diperpanjang dengan menggunakan edible coating dari gelatin kulit sapi. Nasution (2011) menyatakan, bahwa kombinasi bentonit $2 \%$ dan gelatin $0,1 \%$ memberikan hasil baik dalam penjer nihan sari buah apel manalagi. Marzuki, dkk (2011) menyatakan bahwa penam bahan gelatin tulang ikan bandeng sebe sar 0,5\% sebagai co-emulgator dapat menstabilkan emulsi minyak ikan (Oleum lecoris Aselli).

Secara komersial gelatin diper dagangkan bervariasi dari 50-300 Blomm, tanpa ditambah warna, flavor, pengawet dan bahan kimia tambahan (Anonim, 2012). GMIA (Gelatin Manufacturers Institute Of America) merekomendasikan jumlah penggunaan gelatin untuk unsur bahan pangan berdasarkan kekuatan bloom seperti Tabel 2.

Tabel 2. Penggunaan Gelatin Pada Bahan Pangan ( Food Ingredient)

Jenis Produk Pemakaian Kekuatan

Gelatin

(bloom)

\begin{tabular}{lcll}
\hline Produk Susu & $0,2-1,0 \%$ & & \\
Makanan Beku & $0,1-0,5 \%$ & 225 & -250 \\
Gelatin Dessert & $7-9 \%$ & $175-$ & 275 \\
Kembang Gula dan sejenisnya : & \\
- Gummy bears $7-9 \%$ & $200-250$ \\
- Manisan & $1,7-2,5 \%$ & \\
- Lozenges & $0,5-1,0 \%$ & $50-100$ \\
- Wafers & $0,5-1,0 \%$ & $50-100$ \\
Produk Bakery & $1-2,0 \%$ & $225-250$ \\
Produk Daging & $1-5 \%$ & $175-275$ \\
Sari buah, bir, \\
Wine 0,0002-0,015\% & $100-200$
\end{tabular}

Sumber : Anonim. 2012. hal 13.

Hafidz, Raja Mohd; Yakoob; Amin dan Norrfaizan (2011), menyatakan bahwa gelatin dengan kekuatan gel rendah (bloom rendah) juga cocok diguna kan sebagai agent penjernih produk sari buah.

Selain industri pangan, gelatin juga digunakan untuk industri farmasi, fotografi dan industri lainnya. Dalam bidang farmasi, gelatin digunakan untuk bahan pembuat kapsul, pengikat tablet dan pastilles, gelatin dressing, gelatin sponge, surgical powder, 
suppositories, medical research, plasma expander dan mikroen kapsulasi. Dalam fotografi, gelatin dipakai sebagai pengikat bahan yang peka caha ya dan koloid pelindung untuk bahan pembentuk image. Dalam industri kertas digunakan sebagai sizing paper (Wahyuni dan Peranginangin, 2008).

\section{KESIMPULAN}

Industri Kecil dan Menengah barang kulit dan alas kaki pada tahun 2012 mengalami pertumbuhan paling tinggi. Pada pengolahan kulit mentah sebanyak satu ton dihasilkan kulit (leather) 150-200 kg; sisanya berupa limbah; yang berasal dari proses basah / beam house (sebelum penyamakan) seba nyak $80 \%$, dan setelah proses penyamak an /tanning sebanyak $20 \%$. Limbah padat tersebut termasuk kedalam masalah utama, apabila tidak ditangani dengan baik akan menimbulkan masalah dan pencemaran lingkungan.

Pemanfaatan limbah kulit untuk produksi gelatin diharapkan dapat mene kan jumlah limbah, mengurangi beban pencemaran lingkungan, mengurangi/ meniadakan keluhan warga sehubungan dengan pencemaran lingkungan, menja min kelangsungan berusaha. Disamping itu dapat memberikan nilai tambah ekonomi, membuka lapangan usaha dan kerja baru, peningkatan pemanfaatan penggunaan kulit, dan mengurangi ketergantungan impor gelatin.

Limbah padat berupa kulit yang diperoleh sebelum proses penyamakan dapat diolah menjadi gelatin untuk industri pangan. Gelatin yang dihasilkan dapat berupa tipe A atau tipe B tergantung proses yang digunakan. Proses asam akan menghasilkan gelatin tipe $A$ dengan rendemen yang lebih tinggi dari pada proses basa. Proses basa menghasilkan gelatin tipe $B$ dengan karakteristik gelatin seperti berat molekul, viskositas, dan kekuatan gel yang lebih baik dari pada proses asam.
Gelatin yang diperdagangkan memiliki kekuatan gel bervariasi dari 50300 Blomm, tanpa pewarna, flavor, pengawet dan bahan kimia tambahan. Sebagian besar digunakan untuk industri pangan, jumlahnya mencapai $70 \%$ dari total produksi gelatin dunia. Pada industri pangan gelatin digunakan sebagai bahan pembentuk busa, pengikat, penstabil, pengisi, pelapis, pemerkaya gizi, pengendap, pembentuk gel, perekat, peningkat viskositas, pengemulsi, finning agent, crystal modifier dan thickener.

\section{DAFTAR PUSTAKA}

Anonim. 1990. Teknologi Pangan dan Agroin dustri. Volume 1 Nomor 9. 43. Gelatin, hal 133-135. www.warintek.ristek.go.id/pangan_k esehatan/pangan/ipb/Gelatin/pdf (Diakses 17 Juni 2013)

Anonim. 1996. Buku Panduan. Teknologi Pengendalian Dampak Lingkungan, Industri Penyamakan Kulit. Badan Pengendalian Dampak Lingkungan. Jakarta

Anonim. 2010. Gelatin Halal, Gelatin Ha ram.http://www.halalguide.info/201 0/02/02/gelatin-halal-gelatin-haram (Diakses, 12 September 2013)

Anonim. 2012. Gelatin Handbook, GMIA. Gelatin Manufacturers Institute Of America. http://www.gelatin-gmia. com/images/GMIA_Gelatin_Manual_ 2012.pdf (Diakses 17 Juni 2013)

Alihniar, Febriana. 2011. Kajian Implemen tasi Produksi Bersih di Industri Penyamakan Kulit (Kasus Desa Cibuluh, Kecamatan Bogor Utara). Bogor Agricultural University.

Barbooti, MM., Raouf, SR., and Al-Ham dani, FHK. 2008. Optimization of Production of Food Grade Gelatine from Bovine Hide Wastes. Journal Eng \& Tech, Vol 26, No 2, 2008, pp 240-253. 
BPS (Badan Pusat Statistik). 2001-2010. Jumlah Perusahaan Menurut Sub-Sektor dan Nilai Tambah Menurut SubSektor. http://www.bps.go.id/ tab_sub/print.php?id_subyek $=09 \&$ notab=2 dan http://www.bps.go.id/ tab_sub/print.php?id_subyek $=09 \&$ notab $=3$. (Diakses 17 April 2013).

Chaplin, Martin. 2012. Gelatin-London South Bank University. http://www. Isbu.ac.uk/water/hygel.html.

(Diakses 13 September 2013)

Choi, S.S., and Regenstein, J.M. 2000. Physicochemical and Sensory Characteristic of Fish Gelatin. Journal of Food Science, Vol 65, No. 2, 2000, pp194-199

Cole, CGB., Gelatin. 2000. Encyclopedia of Food Science and Technology, 2nd edition, 4 Vols, Ed. JF Frede rick. New York. John Wiley \& Sons, 1183-1188.

Dewi, PR. 2013. Pengusaha Penyamakan Kulit Terancam Penutupan Usaha. http://suarapengusaha.com/2013/0 $1 / 01 /$ pengusaha-penyamakan-kulitterancam-penutupan-usaha. (Diakses 02 April 2013)

Elfrida, SR. 2012. Menggunakan Metoda Elektrokoagulasi Pada Pengolahan Limbah Industri Penyamakan Kulit Menggunakan Alumunium Sebagai Sacrificial Elektroda. Universitas Pendidikan Indonesia. Repository. upi. Edu.

FAO (Food and Agriculture Oganization). 1966. 3.Tanneries http://www.fao. org/WAIRDOCS/LEAD/X6114E/x611 4e05.htm ( Diakses 28 Mei 2013.

Fauzi, Rahmi. 2007. Gelatin. http://www. chem-is-

try.org/artikel_kimia/gelati/ (Diakses 17 Juli 2012).

Hafidz, Raja Mohd, RN., Yaakob, CM., Amin, I., and Noorfaizan, A. 2011. Chemical and functional properties of bovine and porcine skin gelatin". International Food Research journal 18: 813-817(2011).

Hambali, E. dan Suryani, A. 2001. Proses produksi Gelatin dari Kulit Sapi Menggunakan Metoda Ekstraksi Bertahap. Paten No Reg.ID: ID 0018918 Tanggal Pendaftaran 30 A Juli A 2001.

Hasan.2007. Studi Ekstraksi Pada Proses Pembuatan Gelatin Tipe B dari Kulit Sapi.Fakultas Teknologi Pertanian. IPB.Bogor

Hastutiningrum, S. 2009. Pemanfaatan Limbah Kulit Split Industri Penyamakan Kulit Untuk Glue Dengan Hidrolisis Kolagen. Jurnal Teknologi Vol 2 No. 2 Desember 2009. Hal. 208-212.

Hidayah, EN. 2007. Minimasi Limbah Industri Kulit Melalui Optimasi Produksi . Jurnal Teknik Kimia Vol.1. No.2. April 2007, hal 5458. Universitas Pembangunan Nasional Veteran Jatim.

IUE (The International Union Environment Commission ) -2 . 2008. Recomen dation For Tannery Solid By Product Management. Updated 2008 http://www.iultcs.org/pdf/IUE2_200 8 (Diakses 18 April 2013)

Indrasti, NS. dan Fauzi, AM. 2009. Produksi Bersih. Departemen Teknologi Industri Pertanian. Fateta IPB. Bogor.

Irman, S. 2011. Teknologi Pengawetan dan Pengolahan Kulit. http://irma ngasali.blogspot.com/2011/03/tekno logi-pengawetan-dan-pengolahan. html ( Diakses 15 Maret 2013 )

Jaswir, I. 2007. Memahami Gelatin. Artikel Iptek. http://www.beritaiptek.com (Diakses 17 Juli 2012). .

Junianto., Haetami, K. dan Maulina. 2006. Produksi Gelatin Dari Tulang Ikan dan Pemanfaatannya Sebagai Bahan Dasar Pembuatan Cangkang Kapsul. 
Fakultas Perikanan dan Ilmu Kelautan, Universitas Padjadjaran. Bandung.

Kanagaraj, J., Velappan, K.C., Chandra Babu, N.K., and Sadulla, S. 2006.

Solid Wastes Generation In The Leather Industri And Its Utilization For Cleaner Environment A Re view. Journal of Scientific \& Industri al Research. Vol 65, July 2006, pp.541-548.

Kozlov, P.V. 1983. The structure and properties of solid gelatin and the principles of their modification. http://albumen.conservationus.org/library/c20/kozlov1983.html (Diakses 16 September 2013)

Martaningsih, Niniet. 2010. Chemical, Physical, and Thermal Analysis of Gelatin Extracted From Rayfish ( Himantura gerrardi) By Various Acid Pretreatment. http://library.its.ac.id ( Diakses 11 September 2013 )

Marzuki, Asnah., Pakki E. dan Zulfikar F. 2011. Ekstraksi dan penggunaan gelatin Dari Limbah Tulang Ikan Bandeng((Chanos chanos Forskal) Sebagai Emulgator Dalam Formulasi Sediaan Emulsi. Majalah Farmasi dan Farmakologi, Vol. 15 No.2 -Juli 2011, hal 63-67.

Mc Nulty, Mary. 2002.Gelatin (How Pro duct Are Made) Study Guide \& Hom work Help- eNotes.com. http://www. enotes.com/gelatinereference/gela tin/print (Diakses 21 Maret 2013)

Nasution, Fransisca OW. 2011. Aplikasi Bahan Penjernih Sebagai Alternatif Pemecahan Masalah Haze Pada Industri Sari Buah Apel Manalagi (Malus sylvestris Mill). elibrary. ub.ac.id/...456789/28965/1/Aplikasi Bahan...( Diakses 16 September 2013).

Nurhalimah, E. 2010. Comparison of Gelatine Extraction Process of Bovine Hide Split by Acid and Base Process. http://repository.ipb.ac.id/ handle/123456789/61883 (Diakses 18 Juni 2013).

Ozgunay, H., Colak, S., Mutlu, MM., and Akyuz, F. 2007. Characterization of Leather Industry Wastes. Polish Journal of Environ.Stud. Vol.16, No.06 (2007) pp. 867-873.

Pranoto,Yudi. 2006. Potensi Gelatin Ikan Untuk Menggantikan Gelatin Mama lia di Bidang Pangan. Prosiding PATPI, hal S84-S96. lib.ugm.ac.id/ digitasi/upload/1456_MU10050604.p df ( Diakses 12 September 2013).

Pranoto,Yudi. 2008. Pemanfaatan Gelatin ikan dalam Industri Pangan. Food Review Indonesia. http://www.food review.biz/login/preview.php?view\&i $d=55706$ (Diakses 21 Maret 2013).

Prayitno. 2009. Kajian Penerapan Recy cle, Reuse dan Recovery Untuk Proses Produksi Kulit Wet Blue Pada Industri Penyamakan Kulit . Majalah Kulit, Karet dan Plastik, Yogyakarta Vol 25 No.1 Tahun 2009. hal 45-52.

Purwanto,Agus. 2006. Pengaruh Penambahan Gelatin Tipe B (Beef Gelatin), Terhadap Daya Ikat Air, Kecepatan Meleleh, dan Mutu Oorganoleptik Yoghurt Beku. Prodi Hasil Ternak, Fakultas Peternakan, Unibraw, Malang,

Puspita, DI. 2012. Terancam Tutup, Pengusaha Penyamakan Kulit Resah. http:// indonesiarayanews. Com /news/ekbis/12-31-2012. (Diakses 18 April 2013).

Roqayyah. 2011. Impact of Leather Waste.

http://www.studymode.com/ essays /Impact-Of-Leather-Waste-852276. html (Diakses 29 Mei 2013)

Said, MI. 2013 Kulit Sebagai Potensi Ko moditi Ekspor Non Migas. Dinas Peternakan Sulawesi Selatan. http:// disnaksulsel.info/index.php?option= com_docman\&task=doc_view\&gid = 2 (Diakses 02 April 2013). 
Saleh, E. 2004. Teknologi Pengolahan Susu dan Hasil Ikutan Ternak. Prodi Produksi Ternak, Fakultas Pertanian, Universitas Sumatera Utara, Medan. http://library.USU.ac.id/download/fp/ter nak-eniza.pdf ( Diakses 11 September 2013 ).

Suparno,Ono; Covington, Anthony D.;dan Evans,Christine S. 2010. Teknologi Baru Penyamakan Kulit Ramah Lingkungan: Penyamakan Kombina si Menggunakan Penyamak Nabati, Naftol dan Oksazolidin. http://reposi tory,ipb.ac.id/handle/123456789/40 475. (Diakses 26 Maret 2013)

Singh,Saranjit., Rama Rao,K.V., Venugo pal and Manikandan, R. 2002. Alte ration in Dissolution Characteristics of Gelatin-Containing Formulation. http://www.pharmtech.com/pharm tech/data/articlestandard// pharmtech/132002/14096/article.pdf (Diakses 10 September 2013)

Suryamin 2013. Wow Industri Kulit, Listrik, dan Elektronika Tumbuh Pesat di 2012. Kepala Badan Pusat Statistik Jakarta, http://www.lensaindonesia. com/ 2013/02/01/wow-industri (Diakses 13 Maret 2013)

Triatmojo, Suharjono. 2009. Implementasi Produksi Bersih Dalam Penyamak an Kulit Guna Pening katan Efisiensi dan Pencegahan Pencemaran Ling kungan. Pidato Pengukukan Jabat an Guru Besar, UGM, Yogyakarta. http://www.mgb.ugm.ac.id/...ato_p engukuhan.html download $=171 \&$... (Diakses 16 September 2013).

Ulfah, Maria. 2011 Pengaruh konsentrasi Larutan Asam Asetat dan Lama Waktu Perendaman Terhadap Sifat Gelatin Ceker Ayam. Agritech. Vol. 31. No. 3, Agustus 2011
Wahyuni, M. dan Peranginangin, R. 2008. Pebaikan Daya Saing Industri Peri kanan Melalui Pemanfaatan Limbah Non Ekonomis Ikan Menjadi Gelatin. http://www.Ikanmania.wordpress. com/2008/01/01/perbaikan-dayasaing-industri-pengolahan-perikanan (Diakses 18 Maret 2013)

Wikipedia, 2012. Kulit Sapi, ensiklopedia bebas. http://id.wikipedia.org/wiki/ Kulit_sapi (Diakses 25 Maret 2013).

Wulandari, D. 2012. Pemanfaatan Limbah Kulit Sapi Untuk Gelatin Sebagai Edible Coating dalam Memperpan jang Masa Kesegaran Buah Jeruk. Akademi Teknologi Kulit. Yogyakarta.

Vaskova, H., Kolomaznik, K., and Vasek, V. 2013. Hydrolysis Process of Colla gen Protein from Tannery Waste Materials for Production of Biosti mulator and its Mathematical Model. International Journal Of Mathema tical Models And Methods In Apllied Sciences, issue 5, Volume 7. Hal 568575.

Zaenab, 2008. Industri Penyamakan Kulit dan Dampaknya Terhadap Lingkungan Kesehatan Lingkungan Makasar. http://keslingmks.Word press.com/ 2008/08/18/industri-pe nyamakankulit-dan-dampaknya-terhadaplingkungan. (Diakses 02 April 2013).

Zafar, Salman. 2012. Waste Generation in Tanneries. http://www. bioenergy consult.com/ waste-fromtanneries/ (Diakses 29 Mei 2013). 